\title{
Načela in dobre prakse upravljanja občin
}

UDK: 352.008 .2

\author{
Stane Vlaj \\ Fakulteta za upravo, Univerza v Ljubljani \\ stane.vlaj@fu.uni-lj.si
}

\section{IZVLEČEK}

Članek opredeljuje dobro upravljanje občin in pomen takega upravljanja za učinkovito zadovoljevanje skupnih potreb in interesov prebivalcev, za kakovost njihovega življenja, za uveljavljanje demokracije $v$ najmanjših enotah in posledično v vsej državi. Poudarja pomen nekaterih pogojev za uresničevanje demokracije, kot so etični standardi obnašanja lokalnih oblasti, zaupanje občanov v lokalno samoupravo in udeležba občanov pri odločanju.

Opisuje vsebino in pomanjkljivosti Evropske listine lokalne samouprave (MELLS), ki določa skupna pravila za zavarovanje in razvijanje pravic in svoboščin lokalnih oblasti. Nadalje predstavlja priporočila in smernice, ki jih je za lokalno upravljanje sprejela ministrska konferenca Sveta Evrope leta 2005 v Budimpešti.

Obravnava nekatere značilnosti uvajanja lokalne samouprave v Sloveniji, težave v pristojnosti odločanja, premajhno udeležbo državljanov v lokalnem življenju, določila v ustavi in zakonu. Predlaga ustanovitev neodvisne strokovne skupine za reševanje teh vprašanj in usklajevanje njihovih rešitev $z$ evropskimi načeli in standardi.

Ključne besede: lokalna samouprava, primerjalna lokalna samuprava, participacija, lokalne skupnosti

\section{Uvod}

$\checkmark$ Evropi in pri nas se zastavljajo vprašanja, ali je lokalna politika $v$ globalni dobi še vedno pomembna, ali bogatejša družba pomeni manjšo potrebo po udeležbi, ali so ljudje postali bolj samozadostni in manj zainteresirani za kolektivne probleme, ali so politične stranke (način, kako so organizirane in delujejo) še pomembne za razvoj lokalne demokracije, ali se je interes za politiko spremenil ali upada, ali so (nekateri) ljudje postali bolj zainteresirani za neposredno udeležbo kot za predstavniško demokracijo, za neformalno udeležbo kot za udeležbo $v$ institucionalnih formalnih kanalih, za udeležbo ad hoc kot za 


\section{Stane Vlaj}

\section{Načela in dobre prakse upravljanja občin}

splošno kontinuirano angažiranje. Ali evropske države ponujajo svojim državljanom paket instrumentov za udeležbo, ki je v skladu z njihovimi pričakovanji? Kako se usklajuje zahteva po novi politiki z značilnostmi tradicionalnega demokratičnega sistema, kakšen naj bi bil politični sistem, da bi ustrezal zahtevam spreminjajočega se sveta, kako zagotoviti, da bi udeležba državljanov spremenila politične procese, kako doseči, da bo udeležba državljanov bolj pozitivna kot negativna (problem NIMBY)? Katere ukrepe uporabiti za reševanje posebnih problemov posebnih skupin državljanov, kako zagotoviti povečanje interesa za neposredno odločanje ter za sodelovanje pri nevladnih organizacijah in možnosti vključitve civilnopravnih oblik v odločanje na lokalni ravni in kako vključiti tudi najnovejša družboslovna spoznanja, ki presegajo takšno lokalno zaprtost, kakršno utrjuje pravni red? ${ }^{1}$

V ospredje aktualnega dogajanja na področju lokalne samouprave pri nas in $\vee$ Evropi stopajo vprašanja dobrega upravljanja lokalnih skupnosti, ki naj bi zagotovilo čim boljše pogoje za uresničevanje sodobnih potreb prebivalcev. Najprej tistih primarnih, ki omogočajo kakovostno življenje ljudi in njihovih družin na kraju prebivanja $v 21$. stoletju, nato pa potreb višjega ranga - ki pomenijo odpiranje lokalne družbe $v$ širšo regionalno, državno, evropsko in svetovno (globalno) družbo oz. okolje. Kakovost življenja prebivalcev lokalne skupnosti je merilo za oceno demokratičnosti in uspešnosti posamezne družbe oz. države. Lokalna samouprava je namenjena ljudem in njihovim skupnim potrebam in interesom, ki jih povezujejo v lokalno skupnost. Pri tem pa je udeležba prebivalcev pri upravljanju njihove lokalne skupnosti conditio sine qua non.

Sodobna lokalna samouprava zagotavlja zlasti javne službe, kot so oskrba z elektriko, plinom, vodo, odvoz smeti, javni prevoz, telekomunikacije idr., ter zagotavlja demokratični nadzor in vpliv lokalne skupnosti na te službe. Zagotavlja naprave in objekte, stanovanja, zdravstvene prostore, domove za ostarele, predšolske šole, šole itd. Prav tako naj bi lokalne skupnosti bolj skrbele za varstvo in ustvarjanje novih delovnih mest in za napredek pri zagotavljanju možnosti za usposabljanje državljanov. Uveljavlja se dejavnost za krepitev lokalne identitete in krepi se sodelovanje med lokalnimi skupnostmi in med državljani in lokalno oblastjo. Za demokratičnost neke države je bistvenega pomena, da je demokracija zavarovana in deluje v najmanjših enotah, to je v lokalnih skupnostih.

$1 \mathrm{Na}$ vsa ta vprašanja in izzive je mogoče dati pozitivne odgovore le, če bodo izpolnjeni številni drugi pogoji. Npr. za povečano udeležbo prebivalcev v lokalnem javnem življenju: uveljavljanje etike na lokalni ravni, integriteta izvoljenih predstavnikov, učinkovito javno upravljanje, preglednost delovanja lokalnih organov, uporaba novih telekomunikacijskih možnosti za udeležbo prebivalcev pri odločanju v lokalni skupnosti, posebna pozornost mladim, ostarelim, ženskam in ostalim danes ne dovolj zastopanim skupinam $v$ organih lokalne samouprave, idr. Prim. Recomendation Rec (2001) 19 of the Committee of Ministers to member states on the participation of citizens in local public life, Strasbourgh, 6. december 2001. 
Demokracija je usodno odvisna od medsebojnega zaupanja med državljani in tistimi, ki jim služijo in so izvoljeni ali imenovani na javne funkcije. Državljani zaupajo le tistim institucijam, ki ravnajo pravilno. Posledice nezaupanja pa so populizem, absentizem in drugi negativni pojavi. Demokracije ni v družbah, ki nimajo sprejemljivih standardov etičnega obnašanja na vseh ravneh javnega življenja. Ti standardi so pomembni v boju zoper korupcijo, njihova uveljavitev pa promovira kulturo poštenosti in preglednosti med vsemi tistimi, ki imajo javne funkcije. Ti ljudje imajo esencialno odgovornost za vzdrževanje, uveljavitev in podrejanje standardom obnašanja v javnem življenju. Gre za načela objektivnosti, integritete, odgovornosti, odprtosti, poštenosti in zavezanosti javnim interesom. Etični standardi so stalno vodilo za ravnanje in obnašanje tistih, na katere se nanašajo. Ti so osebno odgovorni za boj s korupcijo in uresničevanje visokih standardov vodenja in upravljanja, ki bo v skladu s pravnimi, upravnimi in institucionalnimi okviri, v katerih delujejo, in za uveljavitev takšnega upravljanja med njihovimi kolegi. Nepogrešljivo vlogo in vpliv na kulturo javnega življenja pa imajo tudi civilna družba in mediji.

Lokalna samouprava je del javne uprave ali javnega sektorja. Kot veljajo etični standardi za druge dele javne uprave kot so državna uprava in javne službe, je njihov pomen še večji za ravnanje lokalnih organov. Ljudje presojajo celoten javni sektor, ki naj bi bil odprt in pregleden, na podlagi tistega, s čimer se srečujejo vsakodnevno na kraju njihovega prebivanja. Lokalna (samo)uprava v občini jim je najbližja raven, ki jo najlažje spremljajo in nadzirajo ter v njej najkonkretnejše uresničujejo svojo pravico do soodločanja o javnih zadevah. Etika javnih uslužbencev in lokalno izvoljenih predstavnikov je prvi pogoj za učinkovito lokalno demokracijo.

\section{Acquis Sveta Evrope o demokraciji}

Acquis Sveta Evrope (SE) na področju demokracije (ki vključuje tudi lokalno in regionalno demokracijo) pokaže, kako SE razume demokracijo in kako jo doseči. $^{2}$ Sestavljajo ga konvencije, pogodbe in listine SE, priporočila Odbora

$2 \mathrm{~V}$ Izjavi in Agendi za dobro lokalno in regionalno upravljanje je 14. Konferenca evropskih ministrov za lokalno in regionalno samoupravo (Budimpešta, 24 do 25. februar 2005) med izzivi in prioritetami evropskih držav in SE na področju lokalne in regionalne demokracije izpostavila:

- $\quad$ demokratično državljanstvo in udeležbo na lokalni in regionalni ravni;

- pravni okvir in institucionalno strukturo lokalne in regionalne samouprave;

- lokalne in regionalne finance:

- $\quad$ vodenje in upravljalske zmožnosti lokalnih in regionalnih oblasti;

- javno etiko na lokalni in regionalni ravni. 


\section{Stane Vlaj}

\section{Načela in dobre prakse upravljanja občin}

ministrov, priporočila, resolucije, mnenja in sklepi Parlamentarne skupščine SE, priporočila, resolucije in mnenja Kongresa lokalnih in regionalnih oblasti Evrope (CLRAE), poročila drugih organizacij, ki delujejo pod dežnikom SE, vključno z Evropsko komisijo za demokracijo skozi pravo (Beneška komisija) in Skupino držav zoper korupcijo (GRECO), različna poročila in publikacije, ki podpirajo aktivnosti SE.

Za našo temo je najpomembnejša Evropska listina lokalne samouprave (MELLS), ki evropskim državam, ki so jo ratificirale, nalaga dolžnost spoštovati določene pogoje, načela in pravila. Listina je določila skupna evropska pravila, da bi zavarovala in razvijala pravice in svoboščine lokalnih oblasti. ${ }^{3}$ Po tej listini je pravica do lokalne samouprave eno ključnih demokratičnih načel. Pravica državljanov, da sodelujejo pri opravljanju javnih zadev, se lahko najbolj neposredno uresničuje na lokalni ravni. Lokalna samouprava pa po tej listini označuje pravico in sposobnost lokalnih oblasti, da $v$ mejah zakona urejajo in opravljajo bistveni del javnih zadev $\vee$ lastni pristojnosti in $\vee$ korist lokalnega prebivalstva. To pravico uresničujejo sveti ali skupščine, sestavljene iz članov, ki se izvolijo s svobodnim, tajnim glasovanjem na temelju neposredne, enakopravne in splošne volilne pravice. Sveti ali skupščine imajo lahko izvršilne organe, ki so njim odgovorni. Nič manj niso pomembni zbori državljanov, referendumi ali kakšne druge oblike neposredne udeležbe državljanov, ki jih dopušča zakon.

Obstajajo predlogi za morebitne dopolnitve in izpiljenje posameznih določil MELLS, ki se nanašajo npr. na razmerja med državo in lokalnimi skupnostmi, med lokalnimi oblastmi in državljani (prebivalci, uporabniki, idr.). ${ }^{\mathbf{4}}$ Slabosti listine ovirajo uresničevanje njenih standardov oziroma delajo listino manj učinkovito, kot se je pričakovalo. Spremembe bi lahko dosegli z amandmaji posameznih določb listine ali s sprejemom dodatnih določb (npr. s protokolom). Besedilo je

3 MELLS je mednarodni dokument za zaščito lokalnih svoboščin. Poleg njega obstaja še vrsta mednarodnih dokumentov s področja lokalne in regionalne samouprave, ki jih bo treba upoštevati tudi v RS. Tu gre za Evropsko okvirno konvencijo o čezmejnem sodelovanju teritorialnih skupnosti ali oblasti z dvema dodatnima protokoloma, Konvencijo o udeležbi tujcev v javnem življenju na lokalni ravni, Evropsko listino o regionalnih in manjšinskih jezikih, Konvencijo o udeležbi mladih v lokalnih in regionalnih zadevah, Konvencijo o udeležbi tujcev v lokalnem javnem življenju, Evropsko listino regionalne samouprave, ki je v pripravi in je v ospredju dela Vodilnega odbora SE za lokalno in regionalno demokracijo, in še za druge dokumente.

4 Strokovnjaki menijo, da obstajajo tri glavne oblike za spremembe, ki bi prinesle jasnejše opredelitve načel, ki se nanašajo na lokalno samoupravo. Najbolj radikalna in občutljiva oblika za spremembe so amandmaji za MELLS. Tu je pričakovati političen in praktičen odpor. Pri prvem gre za pričakovano reakcijo, da naj pustijo pri miru to zelo pomembno podlago za mednarodno pravno varstvo lokalne samouprave. $V$ drugem primeru pa bi trajalo zelo dolgo, da bi pridobili soglasno odobritev držav članic SE. Druga možna oblika je sprejem protokola k MELLS, kar je praksa pri številnih drugih mednarodnih instrumentih kot je npr. Evropska konvencija o človekovih pravicah. Protokol bi imel enak pravni status kot listina sama. Tretja možnost pa je, da se k listini sprejme pojasnjevalno poročilo. 
$\checkmark$ nekaterih delih neprecizno in ima zato majhno zavezujočo moč. Razlogi za to so predvsem $v$ avtorjih listine, ki so želeli doseči kompromis ali niso imeli politične volje, da gredo dlje. Eden pogosto kritiziranih primerov je člen 9, ki se nanaša na finančne vire lokalnih oblasti, še zlasti druga točka, ki govori o tem, da morajo biti finančni viri "ustrezni« nalogam, ki jih opravljajo lokalne oblasti. Takšna opredelitev je po mnenju strokovnjakov daleč od jasnosti. Ali pa npr. "zamisel o odgovornosti izvršilnega organa predstavniškemu telesu" (drugi odstavek 3. člena) v primeru, ko sta oba izvoljena neposredno.

Zelo aktualno je razmerje med lokalnimi oblastmi in državljani, kjer listina uporablja tudi formulacijo »in druge oblike neposredne participacije». Le-te pa so lahko tudi posvetovalni sveti znotraj občin za posamezne kategorije prebivalcev - mlade ljudi, tujce, starejše državljane idr., ali za prebivalce specifičnih sosesk. Tudi opredelitev "na ustrezen način (povprašati za mnenje lokalne oblasti - op. av.) je potrebna preciziranja. Takih nejasnih pojmov oziroma opredelitev je še veliko. Npr. da mora biti upravni nadzor "v sorazmerju..."

Razen dopolnitev in izpiljenja nekaterih členov za izboljšanje obstoječega besedila listine, je skupina neodvisnih strokovnjakov za MELLS pri CLRAE pripravila predloge za mogoče reforme $v$ razmerjih med lokalnimi in centralnimi oblastmi v državah članicah SE. Čeprav je izvršilni organ (še zlasti župan) v vse več primerih izvoljen neposredno, lahko obstoj dveh neposredno izvoljenih organov, ki oba uživata identično raven demokratične legitimnosti, ogrozi načelo temeljnega pomena, da je predstavniško telo najpomembnejše, in povzroči blokade znotraj občinskega upravljalskega aparata. Zato bi bilo primerno načrtovati uvedbo sistema, $v$ katerem bi bilo predstavniškemu telesu dovoljeno, da dá na referendum predlog za razrešitev izvršilnega organa (župana).

Za krepitev načel subsidiarnosti in proporcionalnosti (npr. člena 4, 9) bi bilo primerno, da se pripravijo pravila, ki bi specificirala načine, na katere so lokalne oblasti vključene v odločitve centralnih oblasti, ki se nanašajo nanje. Dalje, da bi zavezala države, da se posvetujejo z lokalnimi in regionalnimi oblastmi na ustrezen način in pravočasno o vsakem predlogu, ki bi lahko bistveno prizadel njihove finančne vire. Prav tako pa naj bi zavezovala države, da ustanovijo skupne odbore centralnih in lokalnih oblasti, zato da bi se ovrednotilo ravnovesje med viri lokalnih oblasti in njihovimi obveznostmi.

$\checkmark$ zvezi s financiranjem naj bi država zagotovila ustrezna sredstva za vsak nov prenos odgovornosti oziroma nalog na lokalne oblasti. Država bi morala zagotoviti, da bistveni del virov lokalnih skupnosti predstavljajo njihovi lastni davki in takse, katerih višino določijo v okviru zakona lokalne skupnosti same. 


\section{Stane Vlaj}

\section{Načela in dobre prakse upravljanja občin}

\section{O udeležbi državljanov v lokalnem javnem življenju}

Dialog med državljani in lokalnimi izvoljenimi predstavniki je bistven za lokalno demokracijo, saj krepi zakonitost lokalnih demokratičnih institucij in učinkovitost njihovega delovanja. Po načelu subsidiarnosti morajo lokalne oblasti prevzeti vodilno vlogo pri pospeševanju sodelovanja državljanov. ${ }^{\mathbf{5}}$

Državljanom je treba zagotoviti pravico do dostopa do jasnih in izčrpnih informacij o raznovrstnih zadevah, ki so povezane z njihovo lokalno skupnostjo, in jim dati besedo pri glavnih odločitvah, ki zadevajo njihovo prihodnost.

Nameniti je treba veliko pozornosti komunikaciji med oblastmi in državljani ter spodbujati lokalne vodje, da poudarjajo pomen sodelovanja državljanov in skrbno preučijo njihove zahteve in pričakovanja, tako da se bodo lažje odzvali na potrebe, ki jih izrazijo

Vsestransko se je treba lotiti vprašanj sodelovanja državljanov in pri tem upoštevati ustroj predstavniške demokracije in tudi oblike neposredne udeležbe pri odločanju in upravljanju lokalnih zadev. Izogibati se je treba preveč togim rešitvam in dopustiti eksperimentiranje, tako da se daje prednost pooblastilom in ne določanju pravil. Iz tega sledi, da je treba zagotoviti široko izbiro sredstev za sodelovanje in možnost njihovega kombiniranja ter prilagajanja načina uporabe glede na okoliščine.

Zavedati se je treba, da je pomembno, da so ženske enakopravno zastopane $v$ lokalni politiki. Prav tako, da so otroci in mladina potencial za trajno uravnotežen razvoj lokalnih skupnosti in in imajo zato lahko pomembno vlogo. Priznati in povečati je treba vlogo, ki jo imajo združenja in skupine državljanov kot ključni partnerji pri razvijanju in ohranjanju kulture sodelovanja in kot gonilna sila pri demokratičnem sodelovanju $v$ praksi.

Po priporočilu je treba čim bolj izkoristiti:

- novo informacijsko in komunikacijsko tehnologijo in ukreniti vse potrebno, da lokalne oblasti in drugi javni organi uporabljajo (poleg že ustaljenih in še vedno uporabnih metod, kot so uradni javni razglasi ali uradne publikacije) vsa sredstva za komunikacijo (interaktivne spletne strani, večpredstavne medije),

- posvetovalne oblike odločanja, tj. take, ki vključujejo izmenjavo informacij in mnenj, npr.: javna srečanja državljanov, porote državljanov in različne oblike forumov, skupin, javnih odborov, ki imajo svetovalno ali predlagalno funkcijo; okrogle mize, javnomnenjske raziskave, ankete o uporabnikih itd.

5 Priporočilo Odbora ministrov Sveta Evrope o participaciji državljanov v lokalnem javnem življenju, 2001. 
Zagotoviti je treba, da neposredna udeležba resnično vpliva na odločanje, da so državljani dobro obveščeni o učinku svoje udeležbe in so rezultati jasno opredeljeni.

Redno je treba zbirati informacije o sodelovanju različnih skupin državljanov in ugotoviti, ali so skupine, kot so ženske, mladina, materialno ogrožene družbene skupine in posamezne poklicne skupine, premalo zastopane $v$ izvoljenih organih in/ali igrajo zelo majhno vlogo ali sploh nobene pri volilnih in neposrednih oblikah udeležbe/sodelovanja. ${ }^{6}$

\section{Ministrska konferenca Sveta Evrope v Budimpešti}

SE je na 14. mednarodni konferenci evropskih ministrov, pristojnih za lokalno in regionalno demokracijo ${ }^{7}$, ki je bila februarja 2005 v Budimpešti, poudaril, da mora dobro lokalno in regionalno upravljanje upoštevati acquis in informacijsko bazo SE na področju lokalne in regionalne demokracije.

Države članice SE so dolžne uresničevati acquis in informacijsko bazo SE in se aktivno udeleževati v delu SE na tem področju. Razširjanje dobrega lokalnega in regionalnega upravljanja je glavni cilj, ki ga morajo zasledovati, da bi odgovorile na izzive družbe in na legitimna pričakovanja državljanov. Največji izzivi pa so:

- nizka raven volilne udeležbe na lokalnih in regionalnih volitvah $v$ mnogih državah članicah;

- $\quad$ spremenjene poti za angažiranje državljanov v lokalnem javnem življenju;

- Širjenje udeležbe tujih državljanov v lokalnem javnem življenju;

- zagotavljanje etičnega obnašanja lokalnih in regionalnih oblasti, izvoljenih predstavnikov in uradnikov, ki morajo spoštovati lokalno in regionalno samoupravo enako kot individualne pravice in legitimne interese.

6 Prav tam.

7 Konferenca je obravnavala dve temi:

- Izzivi in prioritete evropskih držav in Sveta Evrope na področju lokalne in regionalne demokracije;

- Rezultati dela po zadnji ministrski konferenci, s posebnim oziom na pravne instrumente o regionalni samoupravi. Tu sta bila poudarjena pomembnost regionalne samouprave in dejstvo, da ta samouprava lahko pomeni obogatitev demokratičnih družb, lahko pomaga pri reševanju novih izzivov dobrega demokratičnega upravljanja in odvisno od razmer lahko odgovori na potrebo, da se javne zadeve opravljajo čim bolj mogoče blizu državljanov. 15. konferenca bo $v$ jeseni 2007 v Valenciji v Španiji in bo nadaljevala razpravo v luči priprave pravnega instrumenta SE (listine ali priporočila) o regionalni samoupravi. 
Stane Vlaj

\section{Načela in dobre prakse upravljanja občin}

$\checkmark$ ta namen so potrebne aktivnosti za:

- za uvedbo Priporočila (2001) o udeležbi državljanov v lokalnem javnem življenju;

- raziskovanje, kako naj uporaba informacijske in komunikacijske tehnologije olajša demokratične reforme na lokalni in regionalni ravni;

- $\quad$ promoviranje priročnika o dobrih praksah javne etike na lokalni ravni in pripravo, in kjer je mogoče, priročnikov, prilagojenih posebnim razmeram $\checkmark$ državah članicah SE idr.

Drugi izzivi so še:

- uveljavitev načela subisidiarnosti z opredelitvijo in zakonsko ureditvijo pristojnosti, strukture in meja lokalnih in regionalnih oblasti;

- spodbujanje in ustvarjanje nujnih pogojev za medobčinsko sodelovanje;

- krepitev učinkovitih odnosov med različnimi ravnmi teritorialne uprave, še posebej med državnimi in lokalnimi oblastmi.

$\checkmark$ državi pa:

- zagotavljanje, da bodo vse lokalne skupnosti (občine) sposobne za samostojno življenje;

- zagotavljanje, da bodo vsi dejavniki v občini - prebivalci, organi, občinska uprava, državni organi - prevzeli pravice in obveznosti v lokalnem upravnem sistemu; $v$ ta namen naj se izdelajo etični kodeksi (na podlagi priročnika SE o javni etiki na lokalni ravni) za vsako občino (pokrajino) posebej;

- zagotavljanje, da so predstavniška telesa kot predstavniki interesov lokalnih prebivalcev - občinski sveti - najvišji organi odločanja v občini;

- zagotavljanje, da bodo država in občine spoštovale ureditev, $\vee$ kateri so enakopravne entitete;

- zagotavljanje novih načinov, pristopov in praks pri povezovanju javnega in zasebnega sektorja na lokalni (občinski) ravni.

\section{Položaj v Sloveniji}

Problemi upravljanja slovenskih občin so veliki. Upravno-organizacijsko gledano so bile ustanovljene številne neracionalne občine. Upada interes prebivalcev za aktivno udeležbo $v$ dogajanjih $\vee$ njihovi občini, organi občine se marsikje obnašajo tako, kot da se jim ni treba povezovati s prebivalci konkretne občine, 
županski položaj je pravno in dejansko premočan, vloga občinskih svetov še ni realizirana, člani občinskih svetov veliko bolj poslušajo svoje politične centrale $v$ Ljubljani kot prisluhnejo konkretnim zahtevam, potrebam in interesom ljudi $v$ občini, ni nobenih sankcij za nemoralno in tudi nezakonito ravnanje občinskih funkcionarjev $v$ času njihovega mandata idr.

$\checkmark$ Sloveniji ne moremo govoriti o kakšni pomembnejši vlogi prebivalcev $v$ lokalnem javnem življenju po uvedbi lokalne samouprave. Odločanje v občini se je preneslo na občinske svete in (pre)močne župane, oblike neposredne udeležbe prebivalcev pri odločanju kot so zbori občanov, lokalni referendumi, državljanska pobuda, ad hoc odbori, organizacije civilne družbe, participacija z uporabo sodobne informacijske tehnologije za soodločanje občanov idr., pa se ne uporabljajo oz. so nerazvite.

Zakon o lokalni samoupravi je sicer vzpostavil organizacijski model, v katerem so najpomembnejše pristojnosti odločanja o javnih zadevah $\vee$ rokah predstavniškega organa (občinskega sveta), izvršilno vlogo $\vee$ občini pa ima neposredno izvoljeni župan. Tretji organ je nadzorni odbor.

Razmerja med občinskim svetom in županom so se zaradi sistema volitev župana (neposredne volitve) pokazala kot problematična. $V$ prvem mandatu občinskih svetov in županov se je izkazalo, da ureditev, v kateri župan ni odgovoren svetu, povzroča blokade $v$ lokalnem upravnem procesu, zlasti v občinah, $\checkmark$ katerih večina $v$ občinskem svetu in župan nimata enakih političnih pogledov.

Problem medsebojnih blokad bi dokončno odpravila sprememba volilnega sistema - to je prehod na posredne volitve župana, česar pa realno ni pričakovati.

Delovno področje občine je po slovenski ustavi izredno ozko in prejudicira majhne, malo pomembne in od države ostro ločene občine. ${ }^{\mathbf{8}}$ Takšna ozka opredelitev delovnega področja občine je samo deloma skladna z usmeritvijo, ki prevladuje $v$ sodobnih evropskih ureditvah in po kateri spadajo $v$ pristojnost občine vse ali vsaj bistveni del lokalnih zadev javnega pomena.

Za nadaljnji razvoj lokalne in pokrajinske samouprave $v$ Sloveniji bi bilo zelo koristno ustanoviti skupino neodvisnih strokovnjakov kot neodvisno strokovno telo, ki bi po zgledu takšne skupine $\vee$ CLRAE skrbela za uresničevanje Evropske listine lokalne samouprave in drugih dokumentov SE v Sloveniji. ${ }^{\boldsymbol{9}}$ Izhajajoč

8 Na referendumih, ki so bili 29. januarja 2006, so volivci izrazili svojo voljo za ustanovitev še 16 novih občin.

9 Tudi v Sloveniji bi lahko bili bolj uspešni pri dograjevanju sistema lokalne samouprave z večjo uporabo dokumentov in študij SE, ki bi jih morali tudi v večji meri prevesti v slovenski jezik. MELLS je v Sloveniji le delno uveljavljen, ob njem pa obstaja še vrsta konvencij, priporočil in študij SE, ki bi jih lahko koristno uporabljali tudi v slovenski teoriji (doktrini) in praksi lokalne samouprave. 


\section{Stane Vlaj}

\section{Načela in dobre prakse upravljanja občin}

iz evropskih načel in standardov ter iz slovenskih razmer in potreb bi lahko skupina s svojimi stališči in pogledi veliko prispevala $\mathrm{k}$ reševanju doktrinarnih in praktičnih vprašanj. ${ }^{\mathbf{1 0}}$

\section{Zaključek}

Demokracija na vseh ravneh družbe je sodobna zahteva, demokracija na lokalni in regionalni ravni pa je prvi pogoj za dobro vladanje in stabilno demokracijo na državni ravni. $V$ Evropi so aktualna vprašanja optimalne delitve pristojnosti, dostopa do finančnih sredstev in oblik vzajemnega sodelovanja državnih, regionalnih in lokalnih ravni oblasti. Iz najnovejših dogajanj v Evropi lahko ugotovimo, da gre razvoj $v$ smeri učinkovite in demokratične oblasti na vseh ravneh. Vsa ta aktualna dogajanja in trendi so vredni temeljitega razmisleka tudi v Sloveniji.

Za demokratični sistem je lokalna demokracija življenjskega pomena in konstitutivni element države. Predstavniška demokracija na lokalni ravni ni dovolj. Udeležba državljanov je predpogoj za dobro lokalno upravljanje. Problem, ki ga opažajo tudi drugod, je nepovezanost politikov z državljani in njihovimi skupinami. Nujna je prenova političnih strank in politike na lokalni ravni.

Ljudje $v$ mnogih evropskih državah izgubljajo zaupanje $v$ javne oblasti tudi na lokalni ravni. Javno mnenje je vse bolj nenaklonjeno nejasnim lokalnim upravljalskim praksam, ki so pogosto združene z zastarelimi političnimi sistemi. Še zlasti varstvo pred korupcijo in drugimi oblikami finančnega kriminala je glavna skrb vseh članic SE. Korupcija ogroža vrednote, za katere se zavzema SE. Korupcija je bolj razširjena, kot je bila npr. pred desetimi leti. To je tudi problem, ki neposredno zadeva organe lokalne oblasti. Dobre rešitve zaščite javne etike in s tem javnih interesov bi morali najti na lokalni ravni. Vsa ta ključna vprašanja so povezana s tem, kako deluje lokalna in regionalna demokracija. Javna etika na lokalni ravni prav tako odstranjuje eno glavnih ovir za decentralizacijo in učinkovito uresničevanja načela subsidiarnosti.

Skrb zbuja upadanje udeležbe državljanov v lokalnem javnem življenju ter odsotnost posvetovanja različnih ravni oblasti z njimi. Neustrezno ravnanje lokalnih oblasti prav tako lahko odbija državljane od udeležbe. $V$ demokratičnih

10 Skupino neodvisnih strokovnjakov kot neodvisno strokovno telo naj bi ustanovila združenja občin. $V$ ustanovitvenem aktu bi določili razmerja med ustanoviteljicami in skupino, ki bi se nato sama konstituirala, sprejela poslovnik o svojem delu, izvolila predsedujočega in začela delovati na podlagi pobud članov, ustanoviteljic in drugih zainteresiranih dejavnikov. 
državah je cilj lokalnih in regionalnih oblasti in države same pospeševati uresničevanje demokracije in zagotoviti najboljši možni odgovor na potrebe ljudi v danih razmerah. Da bi to dosegli, mora obstajati sodelovanje med različnimi ravnmi oblasti, konflikti pa naj se rešujejo z vidika doseganja omenjenih ciljev.

$\checkmark$ procesih upravljanja lokalnih skupnosti, $v$ našem primeru občin, ima vsakdo svojo vlogo - prebivalci, občinski sveti in župani, občinska uprava, javni zavodi in javna podjetja, koncesionarji, zveze občin, bodoče pokrajine, država, mednarodne povezave.

Dr. Stane Vlaj je redno zaposlen kot docent na Fakulteti za upravo, kjer je nosilec predmetov Uvod $v$ javno upravo ter Lokalna samouprava. Je tudi predstojnik Inštituta za lokalno samoupravo, ki se ukvarja s seminarsko dejavnostjo za kadre v lokalnih skupnostih, izdajanjem priročnikov (tu je urednik in soavtor), raziskovalno dejavnostjo in s svetovalnim delom za občine. Je član Društva za ustavno pravo RS, Slovenskega društva za upravne znanosti in Slovenskega politološkega društva.

\section{Literatura in viri}

- Budapest Declaration on Delivering Good Local and Regional Government, 14th session of the Ministerial Conference in Budapest, 24-25 February 2005.

- Statement of the Budapest Ministerial Conference on Regional Self-Government.

- Developing Democracy in Europe, An Analitical summary of the Council of Europe, Integrated project »Making democratic institutions work", Council of Europe, 2004

- Model Initiatives Package on Public Ethics at Local Level, prepared by the Steering Committee on Local and Regional Democracy CDLR), adopted at the International Conference on "Ethical Standards in the Public Sector (Noordwijkerhout, 31 March - 1 April 2004.

- Council of Europe, Committee of Ministers, Recommendation No. R(99)8 of the Committee of Ministers on the financial liability of local elected representatives for acts or omissions in the course of their duties, 17 March 1999.

- Recomendation Rec (2001) 19 of the Committee of Ministers to member states on the participation of citizens in local public life, 6. december 2001.

- Preliminary draft report on "Institutional dialogue between the state, regions, local authorities and their associations", Steering committee on local and regional democracy (CDLR), Strasbourg, 8. april 2002.

- The future of democracy in Europe - trends, analyses, reforms (2004), Strasbourg: Council of Europe Publishing. 


\section{Stane Vlaj}

\section{Načela in dobre prakse upravljanja občin}

- Committee of Ministers Recommendation No. R (97) 3 on youth participation and the future of civil society.

- Committee of Ministers Recommendation No. R (98) 8 on children's participation in family and social life.

- Committee of Ministers Recommendation Rec(2003)3 on balanced participation of women and men in political and public decision making.

- Committee of Ministers Recommendation No. R 2000 (10) on codes of conduct for public officials;

- Congress of Local and Regional Authorities of Europe Recommendation 60 (1999) on political integrity of local and regional elected representatives.

- $\quad$ G. Stoker (1996): "Introduction: Normative theories of local government and local democracy" in D. King and G. Stoker (eds.): Rethinking local democracy, Basingstoke: Macmillan 1996.

- Council of Europe, Consolidated report on the latest developments concerning local and/or regional self-government in member States having signed the European Charter of Local Self-Government with an introduction by Alain DELCAMP, Chair of the Group of Independent Experts, Strasbourg, 6 June 2003.

- Vlaj, S. (2006): Skupina neodvisnih strokovnjakov za lokalno samoupravo, časopis Skupnosti občin Slovenije. 


\section{SUMMARY \\ Principles and Good Practices of Municipality Management}

The article puts in the forefront of the topical development in the field of local self-government in Slovenia and Europe the conditions of good local community management that should ensure the satisfaction of contemporary needs of inhabitants - first of all, of primary needs enabling a good quality of life to people and their families at their locations of residence in the 21st century, but also of the needs of a higher rank, signifying opening of the local society to the broader regional, national, European and global society or environment. Quality of life of local community inhabitants is a criterion for evaluating democracy and success of an individual society or country. The article particularly stresses the significance of some conditions for bringing about democracy, such as ethical standards of behaviour of local authorities, confidence of community members and their participation in decision-making. Here, the author refers to the contents and deficiencies of the European Charter of Local Self-Government (MELLS), specifying common rules for the protection and development of rights and liberties of local authorities. At the end of the article, the author deals in greater detail with the present situation and the introduction of local self-government in Slovenia, covering difficulties related to decision-making powers, insufficient participation of citizens in local developments as well as constitutional and legal provisions.

Ethical standards of local authorities' behaviour as a precondition for an effective local democracy and confidence of citizens in local selfgovernment

Democracy at all levels of society is a contemporary requirement, whereas democracy at local and regional levels is a precondition for good government and stable democracy at the state level. Democracy does not exist in societies that lack acceptable standards of ethical behaviour at all levels of public life. These include the principles of objectivity, integrity, responsibility, openness, honesty and commitment to public interests. Ethical standards are a permanent guideline for action and behaviour of those to whom they pertain. The latter are personally accountable for fighting corruption and for implementing high standards of government and administration, harmonized with legal, administrative and institutional 
Stane Vlaj

Načela in dobre prakse upravljanja občin

frameworks in which they operate, and for the establishment of such administration among their colleagues.

Local self-government is a part of public administration or public sector. Ethical standards are also in force for other spheres of public administration, such as state administration and public services, but their significance is even greater for the action of local bodies. People judge the entire public sector, presumably open and transparent, based on what they come across in their daily lives in their place of residence. For them, local (self)government in the municipality is the closest level which they can most easily monitor and control and where they can exercise their right to participate in decision-making about public issues in the most concrete manner. Ethics of public servants and of locally elected representatives are the precondition for an effective local democracy.

\section{Citizen's participation in decision-making}

Special attention is devoted to citizens' participation in local public life because the dialogue between citizens and locally elected representatives is of crucial importance for local democracy. Citizens' participation in decision-making strengthens the legitimacy of institutions and the effectiveness of their operation. Pursuant to the principle of subsidiarity, local authorities must assume the leading role in promoting citizens' participation. Citizens must be ensured the right to having access to clear and comprehensive information about various issues related to their local community and they must be allowed to express their opinions regarding main decisions concerning their future.

The issues of citizens' participation must be tackled in a comprehensive manner whereby the structure of representative democracy as well as forms of direct participation in decision-making and administration of local affairs must be considered. Excessively rigid solutions must be avoided and experimenting must be allowed, giving preference to authorizations over rule stipulation. Hence it follows that a broad choice of instruments for cooperation as well a possibility of their combination and adjustment of their use with regard to circumstances must be ensured.

It must also be ensured that direct participation actually influences decision-making, that citizens are well informed about the effect of their participation and that the results are clearly defined. 


\section{Situation of local self-government in Slovenia}

This part of the article presents some characteristics of introducing local self-government in Slovenia, such as difficulties related to decisionmaking powers, insufficient participation of citizens in local developments as well as constitutional and legal provisions.

Slovene municipalities are facing serious administration problems. From the administrative and organizational aspect, many decisions to establish municipalities were unreasonable. The interest of citizens for an active participation in developments in their municipality is decreasing, municipal bodies often behave as if they had nothing to do with the inhabitants of their municipalities, mayors have excessive legal and actual powers, the role of municipal councils is not yet realized, members of municipal councils prefer to follow their political parties in the Slovene capital city than to listen to concrete requirements, needs and interests of people in municipalities, there are no sanctions for immoral and unlawful actions of municipal officials during their terms of office, etc.

In Slovenia we cannot talk about a significant role of citizens in local public life after the introduction of local self-government. Decisionmaking in municipalities was transferred to municipal councils and (excessively) powerful mayors; forms of direct citizens' participation in decision-making, such as assemblies of community members, local referenda, civil initiative, ad hoc committees, civil society organizations, participation by using state-of-the-art information technology for citizens' participation in decision-making, etc., are not being used or are underdeveloped.

As a solution, the author suggests an independent expert group to be established to tackle these issues and to bring their recommended solutions into line with European principles and standards. Based on European principles and standards as well as on Slovene circumstances and needs, this group with its standpoints and views could substantially contribute to the solution of doctrinaire and practical issues. 